\title{
Climate change and the forest sector: Perception of principal impacts and of potential options for adaptation
}

\author{
by Mathieu B. Morin ${ }^{1}$, Daniel Kneeshaw², Frédérik Doyon³ ${ }^{3}$ Héloïse Le Goff4, \\ Pierre Bernier ${ }^{5}$, Véronique Yelle ${ }^{6}$, Anne Blondlot ${ }^{7}$ and Daniel Houle 8,9
}

\begin{abstract}
As evidence points to the importance of climate change (CC) impacts on forests, it is critical to understand how forestry and forest-dependent communities will be affected. People active in the Quebec forest sector were consulted about their perceptions on the most important potential impacts and adaptation measures. Preoccupations covered many aspects of natural ecosystems, forest-based communities, and industries. Expected impacts and adaptation measures were grouped according to biomes and sectors. Prioritized impacts included increases in extreme meteorological events and natural disturbances. Impacts were also expected for human or economic systems such as reductions in wood volume and quality, difficulties in accessing forests, and additional costs for forest operations. Adaptation was perceived to come from new policies, a greater awareness, and local and regional adjustments to forest operations and management. Identified barriers to adaptation included lack of knowledge or understanding of CC impacts, lack of scientific support and knowledge transfer, and lack of leadership in CC issues at a regional scale. This synthesis will help orient future needs in climate-sensitive forest management planning and identify ways to increase adaptive capacity of the forest sector.
\end{abstract}

Keywords: climate change, adaptation measures, impacts, perception, barriers to adaptation, forest management, Quebec, Canada, forest sector

\section{RÉSUMÉ}

Les impacts des changements climatiques (CCs) sur la forêt sont déjà observés et iront en samplifiant dans le futur. Dans ce contexte, il importe de comprendre comment les communautés et l'industrie forestière seront affectées. Des professionnels du secteur forestier québécois ont été consultés lors d'un atelier afin de recueillir leurs perceptions des impacts potentiels des CCs et des possibles mesures d’adaptation. Les préoccupations touchaient les écosystèmes naturels, ainsi que les collectivités et l'industrie forestière. Les impacts identifiés incluaient l’augmentation des évènements météorologiques extrêmes et des perturbations naturelles, une diminution quantitative et qualitative du bois, ainsi que de plus grandes difficultés d’accès aux territoires et des coûts additionnels pour les opérations. Les mesures d’adaptation pourraient comprendre de nouvelles règlementations, une meilleure sensibilisation aux enjeux, et des ajustements locaux et régionaux dans la gestion et les opérations. Les barrières à l'adaptation identifiées incluaient une faible compréhension des enjeux au niveau des intervenants du milieu forestier, ainsi qu'un manque de soutien scientifique, de transfert des connaissances, et de leadership à léchelle régionale. Cette synthèse aidera à orienter les besoins en matière de planification et de gestion et à identifier des solutions pour augmenter la capacité dadaptation du secteur forestier.

Mots-clés : changement climatique, mesures d’adaptation, impacts, perception, barrières à l'adaptation, gestion forestière, Québec, Canada, secteur forestier

\footnotetext{
${ }^{1}$ Intern, Ouranos, research consortium on regional climatology and adaptation to climate change, 550 Sherbrooke West, West Tower, 19th floor, Montreal, QC, Canada, H3A 1B9. E-mail: mathieubm@gmail.com

${ }^{2}$ Professor, Centre d'études de la forêt, Université du Québec à Montréal, Case Postale 8888, Succ. Centre-Ville, Montreal, QC, Canada, H3C 3P8. E-mail: kneeshaw.daniel@uqam.ca

${ }^{3}$ Professor, Institute of Temperate Forest Sciences, Université du Québec en Outaouais, 58 rue Principale, Ripon, QC, Canada, J0V 1V0. Email: frederik.doyon@uqo.ca

${ }^{4}$ Advisor, Direction des orientations stratégiques et de l'administration, Ministère des Forêts, de la Faune et des Parcs, 5700, 4e avenue Ouest, Québec, QC, Canada, G1H 6R1. E-mail: heloise.legoff@mffp.gouv.qc.ca

${ }^{5}$ Research scientist, Natural Resources Canada, Canadian Forest Service, Laurentian Forestry Centre, 1055 du P.E.P.S., P.O. Box 10380, Stn. Sainte-Foy, Québec, QC, Canada, G1V 4C7. E-mail: pierre.bernier@rncan-nrcan.gc.ca

${ }^{6}$ Advisor, Direction des orientations stratégiques et de l'administration, Ministère des Forêts, de la Faune et des Parcs, 5700, 4e avenue Ouest, Québec, QC, Canada, G1H 6R1. E-mail: veronique.yelle@mern.gouv.qc.ca

${ }^{7}$ Scientific program coordinator, Ouranos, research consortium on regional climatology and adaptation to climate change, 550 Sherbrooke West, West Tower, 19th floor, Montreal, QC, Canada, H3A 1B9. E-mail: blondlot.anne@ouranos.ca

${ }^{8}$ Research scientist, Direction de la recherche forestière, Ministère des Forêts, de la Faune et des Parcs, 2700 rue Einstein, Québec, QC, Canada, G1P 3W8. * Corresponding author's e-mail: daniel.houle@mffp.gouv.qc.ca

${ }^{9}$ Scientific program coordinator, Ouranos, research consortium on regional climatology and adaptation to climate change, 550 Sherbrooke West, West Tower, 19th floor, Montreal, QC, Canada, H3A 1 B9.
} 


\section{Introduction}

Climate is a key factor influencing forest ecosystems across the planet. It plays a role at different levels, from physiological processes such as photosynthesis (Saxe et al. 2001), respiration (Ryan 1991) and growth (Duchesne et al. 2012, Dufour and Morin 2013), to the geographic distribution of tree species (McKenney et al. 2007, Périé et al. 2014). Given the strong dependency of forests on climate, many impacts on forests are anticipated in the context of climate change, hereinafter CC (Logan et al. 2011). In the last decade, global studies have shown that increased temperatures may be linked to an increase in forest productivity (Gielen and Ceulemans 2001, Nemani et al. 2003, Boisvenue and Running 2006), although the effect of increased $\mathrm{CO}_{2}$ concentration and higher atmospheric nitrogen deposition may have also played a role. More recently studies have also reported more mixed results, noting potential declines in forest productivity and increases in tree mortality in response to higher temperatures and water limitations which may also alter the distribution and composition of forest ecosystems (van Mantgem et al. 2009, Lapointe-Garant et al. 2010, Girardin et al. 2012, 2014; Williams et al. 2013).

Furthermore, climate influences forest structure and composition at stand and landscape scales through disturbances such as forest fires (Weber and Flannigan 1997), insects and pathogens (Ayres and Lombardero 2000, Volney and Fleming 2000, Price et al. 2013). The impact of these disturbances is expected to change in coming decades under the effects of CC (Drever et al. 2009, Ali et al. 2012) and may further impact forest ecosystems through still undetermined feedbacks as plant responses are inherently linked to extreme weather and natural disturbance events (McDowell et al. 2011, Rustad et al. 2012, Price et al. 2013). Forestry and other forest-related activities that significantly contribute to the economy of countries like Canada are likely to be greatly affected (positively and negatively) by CC through multiple, complex mechanisms (Linder at al. 2002, Kirilenko and Sedjo 2007, Lemmen et al. 2008). Consequently, achieving the long-term goals of sustainable forest management under the current paradigm may be strongly jeopardized (Johnston et al. 2010).

In order to cope with the impacts of CC, the science of adaptation has grown considerably during the last two decades (Smit et al. 1999, IPCC 2001, Meinke et al. 2009). We present in Box 1 a few definitions of the main concepts. Adaptation to CC refers to adjustments in ecological, social, and economic systems in response to the effects of changes in climate (Smit et al. 2000) and is generally expressed through adaptation measures. Smit and Pilifosova (2001) described a fundamental shift in the conceptualization of adaptation, from a vision that focused on biophysical impacts during the 1990s (impact assessment), to the concept of vulnerability (vulnerability assessment) that addressed the question of adaptation of the targeted system and its ability to overcome undesired outcomes, i.e., its adaptive capacity (Füssel and Klein 2006, Smit and Wandel 2006, Vogel et al. 2007, Ford et al. 2007; see Box 1). It was acknowledged that vulnerability and adaptive capacity (and the concepts within) are interrelated and vary across scales, context and over time as social and ecological systems continuously evolve (Smit and Wandel 2006).

Adaptive capacity is the resilience of a society to the risks it is facing (Brooks et al. 2005), which implies social, eco-

\section{Box 1. Concepts and definitions underlying adaptation to climate change.}

$\begin{array}{ll}\text { Exposure } & \begin{array}{l}\text { The nature and degree to which a system is } \\ \text { exposed to significant climatic variations (Füssel } \\ \text { and Klein 2006). }\end{array} \\ \text { Sensitivity } & \begin{array}{l}\text { The degree to which a system or species is } \\ \text { affected, either adversely or beneficially, by cli- } \\ \text { mate variability or change (IPCC 2014). }\end{array} \\ \text { Impact } & \begin{array}{l}\text { Consequences of climate change on natural and } \\ \text { human systems (IPCC TAR, 2001). The magni- } \\ \text { tude of the consequence depends on the exposi- } \\ \text { tion to the forcing phenomena and the sensitiv- } \\ \text { ity of the system affected by it (IPCC 2001). }\end{array}\end{array}$

Adaptive The ability of systems, institutions, humans, capacity and other organisms to adjust to potential damage, to take advantage of opportunities, or to respond to consequences (IPCC 2014).

Vulnerability Commonly relates to the exposure and the sensitivity to a certain stress, that it be social, biophysical or both, and the capacity to manage it (i.e., adaptation) (Adger 2006, Gallopín 2006). Vulnerabilities are often considered as a susceptibility to be harmed when an impact occurs, and which can bring a change to the system (IPCC 2001, Adger 2006, Gallopín 2006).

Barriers Obstacles that can be overcome using appropriate resources and which can emerge at any step in the adaptation process, from the initial impact analyses to the implementation or evaluation of adaptation measures (Moser and Ekstrom 2010).

Maladaptation Actions that may lead to increased risk of adverse climate-related outcomes, increased vulnerability to climate change, or diminished welfare, now or in the future (IPCC 2014).

nomic and political determinants (Adger 2006, Magnan 2009, 2010). These determinants refer back to the main spheres of sustainable development and can be associated with barriers to adaptation (Box 1) that impede efforts to develop and apply adaptation measures. Failure to identify and address these barriers may eventually result in delays and lead to higher costs to adaptation or to missed opportunities (Moser and Ekstrom 2010).

One barrier to adaptive capacity that is directly linked to the adaptation process but more rarely addressed, particularly at the regional level, is the perception of forest actors and stakeholders towards the anticipated CC impacts (awareness), the forest sector's vulnerabilities (lucidness), and the possible solutions to address them (readiness). Erroneous assumptions or lack of awareness can lead to poor interest and motivation to make policy and operational decisions despite recognition of the forest sector's sensitivity to CC. Without a clear understanding of the stakeholders' perceptions, adopted measures can lead to maladaptation at the expense of more promising options (see Box 1). In this context, identifying the percep- 
tions of stakeholders can inform us as to their level of knowledge of and concern for CC, their understanding regarding the mechanisms of vulnerability, and whether they are inclined to engage in the adaptation process.

The objectives of this work were to gather such knowledge from the forest sector and report on both perceptions of CC impacts linked to vulnerabilities and the level of comprehension of the mechanisms underlying these impacts and to foster interactions and discussions within Quebec's forest sector. We also present perceived elements favouring and impeding adaptive capacity of the forest sector, as well as related adaptation measures and tools. With the forest sector's adaptation process in mind, these perspectives will contribute to: 1) increase forest-based communities' and professionals' awareness to specific ecological, social and economic risks; 2) improve integration of CC issues in forest management planning; and 3) identify future research priorities for adaptation of forests and forestry to a changing climate.

\section{Methods \\ Workshop scope}

To address the above objectives, a working group from academic, governmental, private and regional organizations in Quebec organised a two-day workshop under the coordination of Ouranos ${ }^{1}$ on the vulnerabilities and impacts of CC on forests, forest operations, and forest management. The province of Quebec has faced multiple challenges over the previous decade, including an economic and forest supply crisis, a recent change in provincial forest management policy and plummeting public confidence in the forest industry, placing the workshop in a particular regional context. However, the overall context is comparable to what other forest industries and governments are going through across the continent and abroad.

\section{Workshop content and program}

During the workshop the first half of each day was planned with presentations dedicated to raise awareness and share the latest information available on the effects of CC at global and regional scales with the workshop participants. The second half of each day was planned with round table sessions using structured group discussion techniques. The first day was devoted to CC impacts while the second addressed the question of adaptation.

To illustrate the potential impacts of CC on forest-related values, the most up-to-date regional projections for the 2050 time horizon were detailed and explained to the participants (Logan et al. 2011). In the province of Quebec, these projections suggest mean annual temperature increases of $3-5^{\circ} \mathrm{C}$ with larger increases in northern Quebec (Logan et al. 2011).

\footnotetext{
${ }^{1}$ Ouranos is a non-profit organization facilitating the networking between forest practitioners, researchers and governmental administrations. Its mission is to acquire and develop knowledge on CC, its derived impacts and related socioeconomic and environmental vulnerabilities in order to inform key decision-makers about probable climate trends and advise them on identifying, assessing, promoting and implementing local and regional adaptation strategies (www.ouranos.ca).
}

Also, the growing season is predicted to lengthen by 20 to 30 days by 2041-2070, compared to 1971-2000. This change would be particularly significant in boreal forests where the current growing season is short. Annual precipitation is also expected to increase, particularly in northern Quebec. However, this increase is largely driven by winter increases in precipitation as little change is projected for the summer season, leading to potential reductions of $20 \%$ to $40 \%$ of summer soil water availability (Houle et al. 2012).

Along with the definition of the main concepts underlying adaptation to $\mathrm{CC}$, the most acknowledged potential impacts of CC on forest-related resources, including forest productivity, composition and natural disturbance, and important socio-economic activities were presented, focusing on the direct and indirect causal mechanisms involved (Doyon et al. 2010). This presentation was followed with examples of elements to consider when evaluating the effects and consequences of CC on certain sectors of activity and how to prioritise.

The first afternoon was dedicated to the identification and prioritisation of current or potential impacts of CC within the forest sector using the World Café facilitation technique (Brown and Isaacs 2005). Evenly distributed groups of participants discussed the topic at hand and once impacts were identified, their analyses were placed on a large board to be shared with all participants. This resulted in an impact grid for which each participant was then asked to add his/her organization's priorities in terms of concerns and actions to be taken (Fig. 1). In accordance with earlier impact and vulnerability assessment methodologies (Spittlehouse and Stewart 2004, Ohlson et al. 2005, Doyon et al. 2012), workshop participants were questioned on CC impacts on specific biomes (i.e., deciduous, mixed and boreal forests) and affected sectors (i.e., resources, services and environment, cultural and natural heritage, public safety). Three sessions were then conducted in parallel, each covering a specific biome. For the purposes of the workshop, we created a "resources" group consisting of professionals and organizations linked with forest planning and management, wood harvesting and processing, maple products and other non-timber forest products, and trapping. Under "services" were grouped recreational land uses such as outdoor recreational and tourist activities including fishing and hunting. Finally, other aspects not directly linked with any particular products or activities but applied to more global components of forest and human systems (such as forest ecological integrity) were grouped under "environment, cultural and natural heritage and public safety".

The second afternoon was devoted to the identification of potential barriers to adaptation and potential elements that could counter these barriers and increase adaptive capacity. Participants were divided in groups of five to six participants. Questions on essential aspects of human and forest systems were presented and explained by workshop organizers to all participants who also received a booklet with the questions. Participants were grouped to answer the questions within a set time period for each question. To ensure input from every participant, the process was conducted as a matrix interview, and results were compiled by group. The complete list of questions is available upon request. 


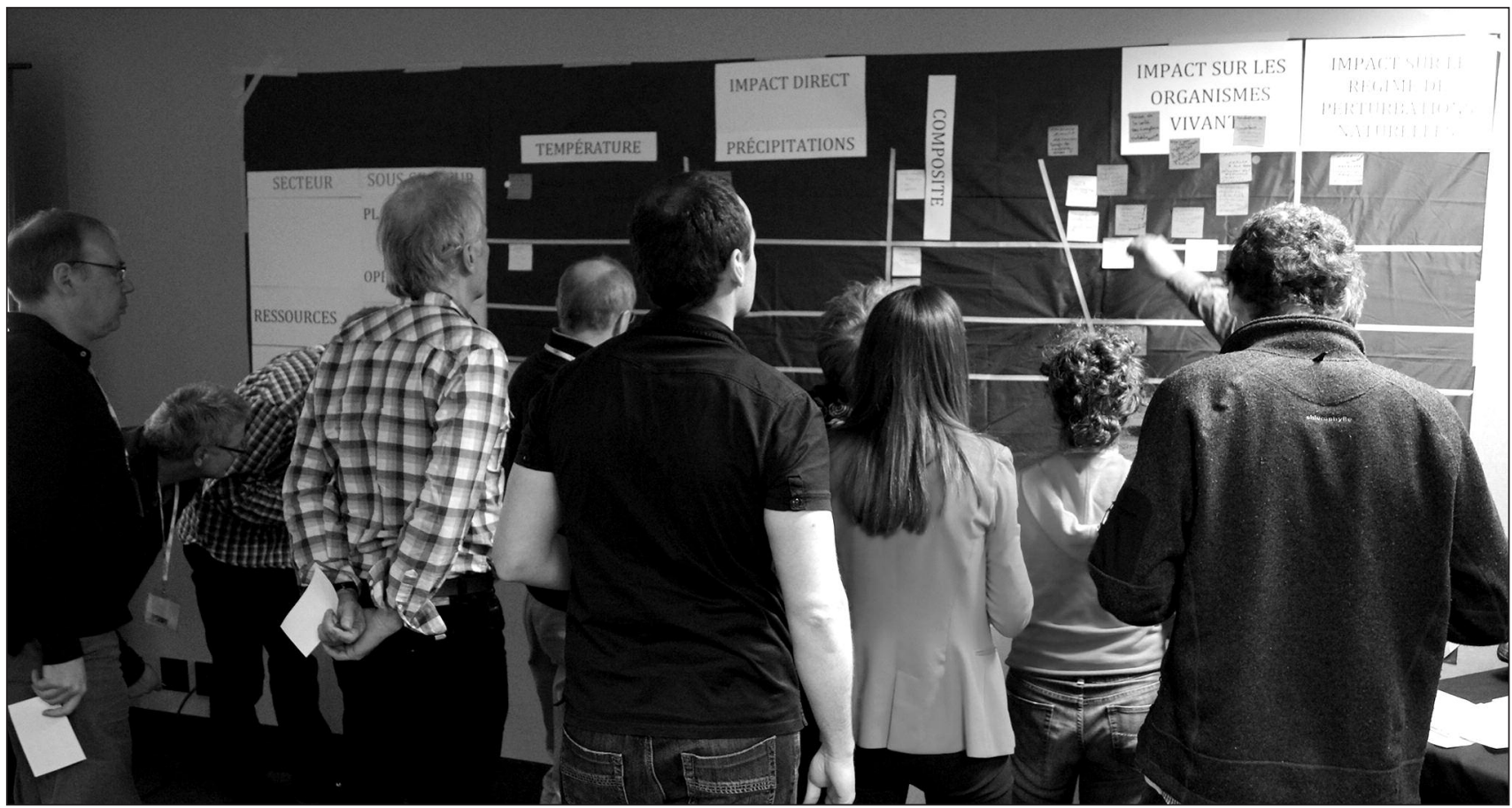

Fig. 1. An impact grid with its priorities at one of the workshop sessions.

\section{Profile of participants}

The workshop was attended by approximately 100 participants from diverse professional backgrounds and institutions, including scientists, managers and policymakers as well as private, community and public organizations (Table 1). Prior to the event, an online survey was conducted to evaluate the knowledge, awareness and sensitivity of people within Quebec's forest sector to the possible impacts of CC and the availability and use of adaptation measures. The survey was distributed via email lists of forestry-related professional organisations. Of the 100 participants to the workshop, 50 responded to the questionnaire.

\section{Main perceptions about climate change}

About $60 \%$ of respondents agreed that CC is already affecting forest ecosystems. This proportion rises to $86 \%$ when future impacts (2050) are considered. These results show that in Quebec, in contrast with the situation reported in British Columbia (Williamson et al. 2005), forest practitioners are reported as being more sensitive to future climate impacts than to current ones. In comparison with $\mathrm{BC}$ practitioners, Quebec foresters have not been as exposed to CC impacts as catastrophic as the mountain pine beetle outbreak, which may explain the difference in perceptions between the two provinces. This difference may likely contribute to lower both the proportion of adaptation measures taken and the level of priority given to adaptation in Québec.

Finally, there was a strong consensus among participants (80\%) that actions should be taken to reduce forest and forest sector vulnerabilities. However, two thirds $(66 \%)$ of the respondents mentioned that the organisation to which they belong considered CC either as a moderate priority or a nonpriority in their current decisions or activities (Yelle and Le Goff, unpublished data).
This situation illustrates that despite available knowledge and people's willingness to act in the forest sector, adaptation to CC is still not integrated into forest management planning. This lack of consideration of potential CC effects in the forest sector identified in the survey underlines the need for workshops in which CC-related issues are discussed with forest sector participants.

\section{Results and Discussion}

Impact perceptions and prioritization

Participants listed a large array of current and potential impacts according to their personal experience and knowledge of the actual CC context, while also identifying adaptation measures or elements that could increase adaptive capacity. Impacts, whether considered globally or for each of the three biomes (deciduous, mixed, and boreal forests), spanned three sectors (resources, services and environment, cultural and natural heritage, public safety) and were grouped into impacts to the forest industry (those that affect planning and those that affect operations), into impacts on forest dependent communities and to changes in natural disturbances. These impacts/vulnerabilities are listed in Table 2, along with the level of prioritization that was given to each of them by the workshop participants (little, moderate or great importance). The results summarized in Table 2 are described and discussed in more detail in the following sections.

\section{Disturbance events}

The projected increased frequency and intensity of extreme meteorological and natural disturbance events was identified as a major concern due to its consequences for the forest industry and forest-dependent communities (Table 2). These extreme events were noted for their potential to affect forest resources (with higher tree mortality rates and reduced pro- 
Table 1. Workshop participants and in the pre-workshop survey, with affiliation in the Quebec forest sector.

\begin{tabular}{lcc}
\hline & $\begin{array}{c}\text { Workshop } \\
\text { participants (\%) } \\
\mathbf{n = 9 6}\end{array}$ & $\begin{array}{c}\text { Pre-workshop } \\
\text { survey } \\
\text { participants (\%) } \\
\mathbf{n}=\mathbf{5 0}\end{array}$ \\
\hline $\begin{array}{l}\text { Affiliation } \\
\text { provincial/federal } \\
\text { public institutions }\end{array}$ & 65 & 78 \\
$\begin{array}{l}\text { Non-governmental } \\
\text { research organizations }\end{array}$ & 15 & 4 \\
$\begin{array}{l}\text { Regional organizations } \\
\text { Industry }\end{array}$ & 12 & 4 \\
Others & 4 & 2 \\
\hline
\end{tabular}

ductive forest area), forest planning and management (with varying wood quotas depending on the intensity of disturbance events) and to generate serious public safety issues (linked to more extensive forest fires that could endanger forest communities particularly in the boreal biome).

Interestingly, the nature of the disturbance event modulated its perceived prioritization, as did the biome in which the participants carried out most of their activities (boreal, mixed or deciduous forests). For example, potential increase in frequency of insect outbreaks and diseases, a major concern for the mixed-forest biome, was superseded by forest fires in the discussion on the more northerly boreal forests. The relative importance of forest fires may relate to their direct destructive potential on infrastructure and communities in the boreal biome, while insects and diseases only directly affect the trees.

\section{Forest planning and operations}

Although many of the expressed concerns were driven by financial considerations, most were linked to the general work flow of the forest sector, from planning to operations and to silviculture. Interestingly, the impacts which were assigned the highest priority (or concern) also received the most attention with regards to identified adaptation measures. These ranged from management planning (e.g., inclusion of CC and natural disturbances in timber supply calculations), to field actions (e.g., lengthening fall operations following early frosts without snow cover) and to address CC effects such as those limiting spring and winter operations. This variety of measures suggests awareness of the main issues and a desire to mainstream adaptation into the planning process.

Impacts with the highest level of concern in all three biomes were the reduction of wood volume and quality, the increase in the complexity of forest management (including higher operation costs), and the uncertainty surrounding the range shifts of tree species (Table 2). A number of participants, however, mentioned that if changes in tree species were to occur slowly, as is expected, the industry would be able to adapt as wood products and industrial structure have changed dramatically during the last decades due to globalization, technological advances in wood hybrid composites, and the arrival of new markets and rival products.
Planning in the face of uncertainty is a problem in natural resource management that will be exacerbated by CC (Millar et al. 2007, Raulier et al. 2013, Gauthier et al. 2014). The relevance of the current planning framework (e.g., legislation and historic benchmarks for forest management based on emulating natural disturbances) was also questioned by participants in mixed and boreal forest sessions, particularly with regards to the integration of current forest protection strategies (e.g., against forest fires) and whether the current framework would remain sustainable in the future. The lack of flexibility of various institutions (at regional, provincial and national levels) responsible for the enforcement of laws and regulations was also mentioned as a potential barrier to adaptation, as in the regional analysis completed by Doyon et al. (2010). The adoption of proactive adaptive management and more adaptive policies to a changing context was therefore seen as an option to favor (Tompkins and Adger 2004, Ogden and Innes 2009, Franklin and Johnson 2012).

Another concern shared by all sectors and impact themes was reduced access to the resource due to the deterioration of forest roads caused by excessive runoff and floods. This concern was not only associated with forest operations but was also considered to be important for native people and remote forest communities.

In the context of CC, high priority impacts to the forest sector were identified more frequently in mixed and boreal forest categories than in temperate deciduous forests. Largescale forestry on public lands in mixed and boreal forest biomes contrast in all aspects with the smaller-scale and varied operations of the mostly-private deciduous forest biome where greater population densities exert more pressure on the resource for multiple uses. This result expresses the importance of considering the social context for identifying vulnerabilities. Such differences among biomes need to be considered when trying to understand stakeholders' perceptions of CC impacts and their corresponding solutions, especially for an area as large as the province of Quebec. This latitudinal variability is also coupled with regional characteristics peculiar to a specific community and ecosystem. Common concerns can be identified across the province, but a custommade, context-sensitive approach (Moser and Ekstrom 2010) must still be developed to favor adaptation, with measures addressing impacts (and the barriers inherently present) with economic, social and ecological aspects.

\section{Communities and social responsibilities}

Other identified impacts were linked to human communities and social responsibilities (i.e., concerns for forest-based communities and industries). For example, potential consequences for hunting, fishing and trapping activities were expressed as being of moderate to high concern (Table 2). These included difficulties in preserving meat because of higher temperatures, increased movement of animals for breeding or habitat needs (Root et al. 2003) and a decrease in fur quality (Cheveau 2010). Participants also identified other potential impacts of shortened winter seasons and higher temperatures on the recreation and tourism sector like snowmobiling (across all biomes) and cross-country skiing (in the hardwood forests which are closer to major cities) which are important economic activities for many forest-based communities. 
IMPACTS - VULNERABILITIES

\section{DISTURBANCE EVENTS}

Intensification of extreme meteorological and natural disturbance events (windfalls, fires, insect outbreaks, ice storms, water stress, (flash) floods, freeze-thaw cycles, heavy snowfalls):

-Increases of tree mortality and decreases of vigor;

-Decreases of productive areas (PLANNING)

More severe and frequent pest outbreaks/diseases

Increase of forest fires intensity duration:

-Impacts on forest planning (PLANNING);

-Impacts on forest fire fighting resources;

-Possible public safety issues in forest communities

(evacuation, etc.) (COMMUNITIES)
-Increasing the rehabilitation of damaged stands; -Specialized labor training required for harvesting disturbed stands;

-Increasing salvage logging;

-Increasing forest ecosystem resilience with

innovative measures (TBD);

-Including CC and natural disturbances in timber supply calculations

-Increasing indigenous and exotic pest monitoring

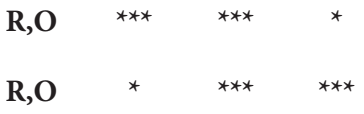

Reduction of forest carbon sequestration potential

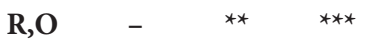

\section{PLANNING}

Reduction of expected returns (volume) of wood products and reduction in wood quality

Relevance of the actual planning framework questioned (e.g., legislations and historic references for the integrated forest management, current forest protection strategies [DISTURBANCE EVENTS])
-Modifying forest planning in accordance with wood products changes

-Establishing an adaptive management favoring a flexible decision-making framework and favoring interdisciplinarity;

-Developing emergency response plans

\section{OPERATIONS}

Shifts in forest management strategies:

-Work planning adjustments

(shorter winter seasons);

-Costs and complexity increases of forest operations;

-Uncertainty surrounding forest operations;

Composition:

-Range shifts of tree species' optimal niches (migration)

Forest territory access difficulties:

-Greater vulnerability related to water/flood;

-Shortened time period to use winter trails;

-Roads degradation, formation of wheel ruts

Forest operations more complex because of compositional changes (more tree species, tradeoffs between present species)
-Longer autumnal operations through early frosts without snow cover;

-Planting different tree species and opting for

alternative silvicultural treatments;

-Introducing cost-benefit analyses of risk management and of non-intervention policies;

-Including CC and natural disturbances in timber supply calculations

-Planting alternate tree species according to their predicted distribution;

-Using more noble tree species in the future;

-New species available in some regions

-Infrastructure enhancements in accordance with future conditions to assure territory access
$\mathbf{R}, \mathbf{O}$

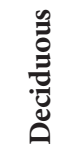

Forest biome

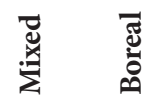




\begin{tabular}{|c|c|c|c|c|}
\hline ELEMENTS - MEASURES OF ADAPTATION & 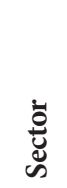 & 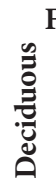 & 总 & 苛 \\
\hline \multicolumn{5}{|l|}{ EFFETS ON COMMUNITIES / SOCIAL RESPONSIBILITY } \\
\hline $\begin{array}{l}\text { Emerging difficulties for hunting, fishing and } \\
\text { trapping activities: } \\
\text {-More problems to keep the meat in fresh condition; } \\
\text {-Increase of animal movements (migration); } \\
\text {-Forest composition and/or forest structures } \\
\text { shifts of wildlife habitats (DISTURBANCE EVENTS); } \\
\text {-Deterioration of fur quality }\end{array}$ & $\mathbf{R}, \mathbf{S}$ & ** & $* * *$ & $* * *$ \\
\hline $\begin{array}{l}\text { Emerging difficulties for the recreational and touristic } \\
\text { sectors (snowmobiles, ski, ...): } \\
\text {-Shortened winter season; } \\
\text {-Damaged winter trails }\end{array}$ & $\mathbf{S}$ & $* *$ & $* * *$ & * \\
\hline $\begin{array}{l}\text { Introduction of new plant species (some undesirable), } \\
\text { possible need to use phytocides }\end{array}$ & $\mathrm{R}, \mathrm{O}$ & $* * *$ & $* * *$ & - \\
\hline Potential loss of representativeness of protected areas & $\mathbf{O}$ & - & $* * *$ & $* * *$ \\
\hline $\begin{array}{l}\text { Conversion of forested lands into farm or inhabited lands: } \\
\text {-Potential source of conflicts }\end{array}$ & $\mathbf{R}$ & - & $* *$ & $* * *$ \\
\hline -Traveling difficulties for native people in isolated areas & $\mathbf{O}$ & - & $* * *$ & - \\
\hline $\begin{array}{l}\text { Expected productivity decline for the maple syrup } \\
\text { industry (closing of smaller sugar shacks during bad years) }\end{array}$ & $\mathbf{R}$ & ** & * & - \\
\hline $\begin{array}{l}\text { Historical references won't be suitable anymore } \\
\text { (ancestral knowledge won't be applicable) }\end{array}$ & O & * & $* *$ & - \\
\hline
\end{tabular}

${ }^{\star}$ Mentioned, but no or little prioritization

** Prioritization: moderate importance

${ }_{* * *}$ Prioritization: great importance

Sector: R: Resources, S: Services, O: Others (Environment, cultural/natural heritage and public safety)

Capital letter words in parentheses in the column "Impacts - Vulnerabilities" indicate when such impacts and/or vulnerabilities are linked to a subcategory different than their main one (i.e., disturbance events, planning, communities).

\section{Adaptation measures}

It is important to mention that despite being numerous, adaptation measures were not identified for every impact (Table 2). Overall, the adaptation measures most often identified were those that would reduce uncertainty and associated risks. These included the establishment of adaptive management strategies with field verifications of gaps between expected versus observed effects (of policies, management targets or silvicultural treatments) followed by rapid adjustment (in terms of research or forest products) or improvements (in techniques used in operations). This predominant choice by participants shows the perceived importance of active adaptive management techniques over passive adaptive management techniques (Duinker and Trevisan 2003, Williams 2011). Shortening forest planning horizons and including CC and natural disturbances at all stages of planning were also identified as possible measures to reduce vulnerability. For field operations, reorganizing access to forest territories considering the potential for extreme meteorological events was considered an important way to reduce risks. Generally, these measures were seen as easy to implement to counter some CC impacts in the near future.

Other adaptation measures may be seen as more difficult to implement, i.e., with constraints on feasibility, or as having a longer implementation time frame with uncertain positive results. These included measures that would modify forest or landscape structures such as planting fast-growing tree species or assisted migration through the planting of trees better adapted to future climate conditions at a given location. Assisted migration (see special issue of The Forestry Chronicle 87(6) December 2011) is a complex issue as it implies a capacity to predict future climatic dynamics. Phenotypic plasticity in trees may be sufficient for many conditions related to CC, as many long-lived adult trees have gone through large varia- 
tions in climate through their lives. However, the seedling stage is the most vulnerable to climatic stresses and participants from the industrial sector noted that planting for future conditions could cause greater plantation failure under current conditions.

Another proposed adaptation measure was the modification of stand or landscape species or structural diversity in order to be more resilient to CC in the long-term. Greater tree diversity is consistent with theories such as the insurance policy which proposes that a greater diversity should ensure that at least some species will maintain their productivity or, in the worst case, will survive (Figge 2004, Knoke et al. 2005). Diversification is thus similar to a bet-hedging policy in which managers recognize that current knowledge is insufficient to plan for a 'best' species and that managing for multiple species will ensure that not all investments will be lost. With careful planning this approach could be integrated with facilitated migration if multiple species and genotypes are moved. However, these actions are based upon slow processes and any result would become perceptible only after a long period of time, as our control over the entirety of forest territories is relatively small (see Metsaranta et al. 2011 for an example in western Canada). The success of these measures would also depend on direct CC impacts on forest operations and on increased natural disturbance events and uncertainty. On the other hand, disturbances could also be considered an opportunity as they would provide managers with the opportunity to accelerate tree diversity through management efforts, as long as the costs are reasonable. In this context, socio-economic studies would be particularly relevant for forest managers.

\section{Barriers to adaptation and element-favoring adaptation}

Participants also identified potential barriers and perceived deficiencies in adaptive capacity that could prevent full implementation of CC adaptation measures within the forest sector. Barriers were identified at several management levels or involved multiple areas of the forest sector, and were thus divided among: 1) knowledge and innovation capital; 2) social capital; and, 3) governance (Table 3). The majority of the elements favoring adaptation were typically more or less the opposite of the barriers, so only the barriers will be discussed further. Many identified barriers linked to issues of coordination and cooperation between forest practitioners, lack of knowledge that would otherwise increase their understanding of CC issues at hand-including possible ramifications in related sectors-and lack of tools to deal with CC impacts in their everyday professional activities.

Many barriers to adaptation identified by participants were related to the lack of adaptive capacity. These included insufficient financial resources and expertise that would hinder the capacity of the forest sector to develop and implement concrete adaptation measures. Financial resources are essential to mitigate economic impacts and respond to any given stress (Smit and Pilifosova 2001). Additionally, a deficiency of qualified personnel can prevent a group, community or society from implementing successful adaptation measures (Scheraga and Grambsch 1998). This group of barriers were identified as an issue in coming years when specific technical expertise would be required to implement adaptation strategies, a clear sign of the need for training professionals to support adaptation.
Weak social capital was also identified as a concern for successful adaptation, particularly in relation to the lack of cohesion and leadership within a community. According to Putnam (1993), social capital can be defined as the "features of social organization, such as networks, norms, and trust, that facilitate coordination and cooperation for mutual benefit". A first step to address this issue may be to better define the roles and responsibilities for each player within the forest sector with respect to $\mathrm{CC}$ adaptation. This would ensure improved cohesion and contribute to developing more efficient adaptation strategies.

As with Smit and Pilifosova (2001), Adger et al. (2008) recognize that scientific knowledge is produced and diffused within society in a way that can also be a barrier to adaptation. Ogden and Innes (2007) suggest that inefficient transfer of scientific knowledge (such as inadequate mediums or language level) or an insufficient time given to stakeholders for reading documentation and assimilating new knowledge on CC are barriers to adaptive practices by forest practitioners. Solving these issues is one of the crucial elements that may contribute to a successful adaptation process. It was clear from the participants' responses that bridging the gap between scientific knowledge and the capacity to implement or integrate this knowledge into management plans, forest operations and other community level activities will be a key element to long-term success in adapting to climate change.

Whether considered in terms of political-institutional structure (Magnan 2009) or governance (Folke et al. 2005), mechanisms governing the functioning of a given land or territory are important determinants of its adaptive capacity. The rigidity of administrative structures in complex hierarchical organizations and the resulting inability to respond rapidly to predictable impacts (Diamond 2000) were also identified by the participants as a barrier to adaptation (Table 3 ). From their perspective, rigidity of regulatory frameworks, often characterised by cumbersome administrative processes is a critical barrier and will be increasingly problematic as changes occur. Furthermore, the lack of collaboration and communication between forest-associated institutions and individuals, from scientists to managers and policymakers (Fettig et al. 2013), was also identified as another barrier that should be tackled immediately.

Finally, as mentioned earlier, the uncertainty in projected CC such as changes in extreme meteorological events at local and regional scales, and in the impacts related to such changes were also identified as a barrier to the adaptation process. Uncertainties concerning local and regional impacts of CC are linked to the inherent natural variability of climate across large territories ( Kerr 2011, Deser et al. 2012). The level of support for adaptation options should be set as a function of their capacity to increase resilience to CC scenarios (Ogden and Innes 2009) and to reduce risks related to uncertainty. Despite uncertainties, several modelling efforts have been conducted world-wide to help understand future impacts of CC on human well-being (Loehle and LeBlanc 1996, Milad et al. 2011) and to inform forest practitioners and policymakers on the potential of policies and strategies for decreasing the risks associated with climate variability and change. However, the inclusion of such uncertainty in forest planning will require further efforts as most forest management tools are based on optimisation approaches, thereby preventing the explicit 
Table 3. Elements influencing negatively (barriers) and positively (favoring) adaptation, as described by the workshop participants and subsequently sorted according to their associated adaptive capacity determinants within the forest sector.

\begin{tabular}{|c|c|}
\hline $\begin{array}{l}\text { Determinants } \\
\text { of the adaptive } \\
\text { capacity }\end{array}$ & Barriers to adaptation \\
\hline $\begin{array}{l}\text { Knowledge and } \\
\text { innovation capital }\end{array}$ & $\begin{array}{l}\text { General lack of knowledge on CC impacts } \\
\text { Lack of scientific support and of knowledge transfer to } \\
\text { forest practitioners } \\
\text { Lack of funding for the development of adaptation } \\
\text { strategies and the implementation of preventive measures } \\
\text { Need for a more skilled and specialised workforce } \\
\text { (for forest operations) } \\
\text { Lack of tools (procedures, techniques, etc.) for the } \\
\text { inclusion of CC in forest planning }\end{array}$ \\
\hline Social capital & $\begin{array}{l}\text { Lack of leadership, willpower and political courage } \\
\text { Lack of cohesion and diverging visions between } \\
\text { practitioners and active groups on forest planning and } \\
\text { management } \\
\text { Low vigilance of practitioners on CC issues and feeling of } \\
\text { impotence because of uncertainty, too-distant horizon of } \\
\text { the objectives compared to daily tasks, gap between actions } \\
\text { and observable impacts }\end{array}$ \\
\hline Governance & $\begin{array}{l}\text { Lack of flexibility of administration structures } \\
\text { (associated with forest planning) } \\
\text { Cumbersome administrative procedures of forest } \\
\text { certification } \\
\text { Lack of precision concerning practitioners' roles and } \\
\text { responsibilities in the forest sector adaptation process } \\
\text { Rigidity of norms and regulation of management planning } \\
\text { Existing framework and tools adapted to manage local } \\
\text { and regional issues (more uncertainty) }\end{array}$ \\
\hline
\end{tabular}

Elements favoring adaptation

Training and increasing the awareness at different levels (professionals /scientists /politicians /decision-makers)

Scientific knowledge transfer with the use of tangible examples

Development of climate models delivering more precise projections

Building a monitoring program to record current CC impacts and future ones

Writing targeted guides and supporting scientific documents

Willpower and political courage

Increasing knowledge on how to manage forests under CC constraints

Integrating local and regional strategies

Existing framework and tools adapted to manage local and regional issues

Long-term strategies allowed by a global vision across sectors

Integrating adaptation measures into the planning and management procedures

Planning and management funding increases

inclusion of uncertainty in crucial tasks such as the annual allowable cut. Taken together, barriers linked to exclusion of uncertainty can seriously hinder innovation and the use of the collective wisdom of forest practitioners in developing creative solutions for adaptation to CC.

\section{Opportunities}

Participants identified positive as well as negative consequences of CC for forest resources and communities. Positive effects could be the motivation to act and change current modes of operation. For example, CC could potentially increase wood resource availability in some areas, which could promote the expansion of non-timber forest-related industries. Benefits could also arise from a change in competitive advantages of specific economic sectors (e.g., maple syrup production in Quebec will compensate for regions in the United States or southern Ontario that will suffer production loss due to less favorable weather).

Participants also found possible opportunities in the modification of business models such as extending summer seasons for outdoor recreation and tourism activities or reshaping the product and services offered and venturing into new market segments depending on CC-induced modifications (e.g., the expansion of wild turkeys into Québec). The willingness to take advantage of change reflects a capacity to innovate that will be a valuable asset in a changing environment.

\section{Workshop overview}

The state of knowledge and level of comprehension in local and regional contexts presented above were evaluated through a workshop during which we were able to sample forest professionals' comprehension and perceptions of CC 
and of its effects on the forest sector. The workshop was also structured to enhance knowledge exchange between individuals acting at different levels of forest management, facilitating group learning and enabling better adaptation capacity in the forest sector, similar to problem-structuring methods (Khadka et al. 2013). Benefitting from participants' inputs, experiences and context, we were able to assess shared elements (as well as those that are biome specific) in terms of perceived barriers and elements favouring adaptation. Even though the effectiveness of the barrier approach to promote decision-making on adaptation to CC has been recently challenged (Biesbroek et al. 2015), we think the information acquired through this method of experience sharing is extremely valuable when trying to understand gaps in the adaptation process and to promote the most promising measures and opportunities. Indeed, there is a need to further support participatory forest planning with workshops and inputs from professionals such as stakeholders, and governmental bodies have a strategic role to play in coordinating these approaches in order to strengthen adaptive capacity. The workshop and its analysis is meant to be part of the adaptation process and was as a guide pointing to more structured and proactive planning strategies for the future.

\section{Conclusion}

There is an increasing need for scientists and forest practitioners to exchange information and to participate in common reflection. The scientific literature on CC, albeit having increased substantially over the last few years (Berrang-Ford et al. 2011), can still be complex and hard to translate into real interventions for forest practitioners, forest users, forest managers and policymakers. As Berrang-Ford et al. (2011) highlight in their review, it is critical to start understanding how research is used within the higher levels of policy-making, as most of the recent proactive adaptation measures linked to $\mathrm{CC}$ are coming from governmental institutions. A question is then: How can this knowledge be transposed into real adaptation measures in the field and in forest-based communities? Furthermore, it is important to recognize the complexity of $\mathrm{CC}$ and associated risks within the forest sector. As Davidson et al. (2003) point out, a significant proportion of laypersons within forest-based communities may not understand the relationships between CC and its impacts, resulting in not perceiving $\mathrm{CC}$ as a real issue. Such knowledge gaps can also be found in managers and policymakers and can thus impede the establishment of proactive strategies dealing with CC impacts and/or development of opportunities. Simple and accessible transfer of research knowledge is thus needed to guide and generate new opportunities (Spittlehouse and Stewart 2004, Ohlson et al. 2005).

Attenuating barriers to adaptation can be seen as an opportunity not only to improve adaptive capacity but also to reinforce conditions favorable for ensuring sustainable forest management in the planning and implementation processes. Improving awareness of forest managers in terms of climate and adaptation information will facilitate the development of adaptive measures. In addition, forest managers need to better understand CC impacts and how they will affect their practices. These two aspects will contribute to build a common and shared vision of adaptation priorities for the forest sector. By scientifically detailing the experience conducted within the workshop, we have assessed how such an exercise could contribute to building adaptive capacity around increased awareness, lucidness and readiness of forest sector actors and could be used as a guide by others.

\section{Acknowledgments}

We thank the workshop's organizing committee: V. BourduasCrouhen $^{2}$, A. Blondlot ${ }^{2}$, N. Beaulieu ${ }^{3}$, P. Bernier ${ }^{4}$, M. Campagna $^{5}$, F. Doyon ${ }^{6}$, H. Falardeau ${ }^{7}$, C.-É. Guertin ${ }^{8}$, D. Houle ${ }^{2,5}$, D. Kneeshaw ${ }^{9}$, H. Le Goff ${ }^{10}$, C. Périé ${ }^{5}$, F. Raymond ${ }^{11}$, C. SteMarie $^{4}$, and V. Yelle ${ }^{10}$. Special thanks is given to C. Ste-Marie, $\mathrm{H}$. Falardeau and M. Campagna who participated in initial discussions and provided helpful comments on early stages of the manuscript. We are also grateful to all participants in the workshop who provided the core results of this research. Finally, we thank Travis Logan ${ }^{2}$ for his help in revising the English.

\section{References}

Adger, W.N. 2006. Vulnerability. Glob. Environ. Chang. 16(3): 268-281. doi:10.1016/j.gloenvcha.2006.02.006.

Adger, W.N., S. Dessai, M. Goulden, M. Hulme, I. Lorenzoni, D.R. Nelson, L.O. Naess, J. Wolf and A. Wreford. 2008. Are there social limits to adaptation to climate change? Clim. Change 93(3-4): 335-354. doi:10.1007/s10584-008-9520-Z.

Ali, A.A., O. Blarquez, M.P. Girardin, C. Hély, F. Tinquaut, A. El Guellab, V. Valsecchi, A. Terrier, L. Bremond, A. Genries, S. Gauthier and Y. Bergeron. 2012. Control of the multimillennial wildfire size in boreal North America by spring climatic conditions. Proc. Natl. Acad. Sci. U. S. A. 109(51): 20966-70. doi:10.1073/pnas. 1203467109.

Ayres, M.P. and M.J. Lombardero. 2000. Assessing the consequences of global change for forest disturbance from herbivores and pathogens. Sci. Total Environ. 262(3): 263-286. doi:10.1016/S00489697(00)00528-3.

Berrang-Ford, L., J.D. Ford and J. Paterson. 2011. Are we adapting to climate change? Glob. Environ. Chang. 21(1): 25-33. doi:10.1016/ j.gloenvcha.2010.09.012.

Biesbroek, R., J. Dupuis, A. Jordan, A. Wellstead, M. Howlett, P. Cairney, J. Rayner and D. Davidson. 2015. Opening up the black box of adaptation decision-making. Nat. Clim. Chang. 5: 493-494. doi:10.1038/nclimate2615

Boisvenue, C. and S.W. Running. 2006. Impacts of climate change on natural forest productivity - Evidence since the middle of the 20th century. Glob. Chang. Biol. 12(5): 862-882. doi:10.1111/j.13652486.2006.01134.x.

Brooks, N., W.N. Adger and P.M. Kelly. 2005. The determinants of vulnerability and adaptive capacity at the national level and the implications for adaptation. Glob. Environ. Chang. 15(2): 151-163. doi:10.1016/j.gloenvcha.2004.12.006.

Brown, J. and D. Isaacs. 2005. The world café: Shaping our future through conversations that matter. Berrett-Koehler Publishers, San Francisco, CA.

${ }^{2}$ Ouranos $;{ }^{3}$ Resolute Forest Products ; ${ }^{4}$ Natural Resources Canada, Canadian Forest Service ; ${ }^{5}$ Direction de la recherche forestière, Ministère des Forêts, de la Faune et des Parcs ; ${ }^{6}$ Institute of Temperate Forest Sciences, Université du Québec en Outaouais ; ${ }^{7}$ Direction de l'aménagement et de l'environnement forestiers, Ministère des Forêts, de la Faune et des Parcs ; ${ }^{8}$ Quebec Wood Export Bureau ; ${ }^{9}$ Centre d'études de la forêt, Université du Québec à Montréal ; ${ }^{10}$ Direction des orientations stratégiques et de l'administration, Ministère des Forêts, de la Faune et des Parcs ; ${ }^{11}$ Conférence nationale des élus de la Capitale-Nationale. 
Cheveau, M. 2010. Effets multiscalaires de la fragmentation de la forêt par l'aménagement forestier sur la martre d'Amérique en forêt boréale de l'Est du Canada. Thesis. Université du Québec en AbitibiTémiscamingue, Rouyn-Noranda, QC.

Davidson, D.J., T. Williamson and J.R. Parkins. 2003. Understanding climate change risk and vulnerability in northern forestbased communities. Can. J. For. Res. 33(11): 2252-2261. doi:10.1139/x03-138.

Deser, C., R. Knutti, S. Solomon and A.S. Phillips. 2012. Communication of the role of natural variability in future North American climate. Nat. Clim. Chang. 2(11): 775-779. doi:10.1038/nclimate1562.

Diamond, J. 2000. De l'inégalité parmi les sociétés : essai sur l'homme et l'environnement dans l'histoire. Gallimard, Paris.

Doyon, F., D. Cyr, J. Poirier, G. Chiasson and S. Boukendour. 2010. Identification des vulnérabilités biophysiques face aux changements climatiques sur le territoire de la collectivité forestière du Projet Le Bourdon (Canada). Ripon, Qc.

Doyon, F., D. Cyr, A. Montpetit, G. Chiasson and É. Plassin. 2012. Évaluation des vulnérabilités et de l'adaptation face aux changements climatiques sur le territoire de la collectivité forestière du Projet Le Bourdon (Canada).

Drever, C.R., Y. Bergeron, M.C. Drever, M. Flannigan, T. Logan and C. Messier. 2009. Effects of climate on occurrence and size of large fires in a northern hardwood landscape: Historical trends, forecasts, and implications for climate change in Témiscamingue, Québec. Appl. Veg. Sci. 12(3): 261-272. doi:10.1111/j.1654-109X. 2009.01035.x.

Duchesne, L., D. Houle and L. D'Orangeville. 2012. Influence of climate on seasonal patterns of stem increment of balsam fir in a boreal forest of Québec, Canada. Agric. For. Meteorol. 162-163: 108-114. doi:10.1016/j.agrformet.2012.04.016.

Dufour, B. and H. Morin. 2013. Climatic control of tracheid production of black spruce in dense mesic stands of eastern Canada. Tree Physiol. 33(2): 175-186. doi:10.1093/treephys/tps126.

Duinker, P.N. and L.M. Trevisan. 2003. Adaptive management: progress and prospects for Canadian forests. In: Burton, P.J., Messier, C., Smith, D.W., Adamowicz, W.L. (Eds.), Towards Sustainable Management of the Boreal Forest. NRC Research Press, pp. 857-892. doi:10.1139/9780660187624.

Fettig, C.J., M.L. Reid, B.J. Bentz, S. Sevanto, D.L. Spittlehouse and T. Wang. 2013. Changing climates, changing forests: A Western North American perspective. J. For. 111(3): 214-228. doi:10.5849/ jof.12-085.

Figge, F. 2004. Bio-folio: Applying portfolio theory to biodiversity. Biodivers. Conserv. 13(4): 827-849. doi:10.1023/B:BIOC. 0000011729.93889.34.

Folke, C., T. Hahn, P. Olsson and J. Norberg. 2005. Adaptive governance of social-ecological systems. Annu. Rev. Environ. Resour. 30(1): 441-473. doi:10.1146/annurev.energy.30.050504.144511.

Ford, J., T. Pearce, B. Smit, J. Wandel, M. Allurut, K. Shappa, H. Ittusujurat and K. Qrunnut. 2007. Reducing vulnerability to climate change in the Arctic: The case of Nunavut, Canada. Arctic. 60(2): 150-166. doi:10.2307/40513131.

Franklin, J.F. and K.N. Johnson. 2012. A Restoration Framework for Federal Forests in the Pacific Northwest. J. For. 110(8): 429-439. doi:http://dx.doi.org/10.5849/jof.10-006.

Füssel, H.M. and R.J.T. Klein. 2006. Climate change vulnerability assessments: An evolution of conceptual thinking. Clim. Change. 75(3): 301-329. doi:10.1007/s10584-006-0329-3.

Gallopín, G.C. 2006. Linkages between vulnerability, resilience, and adaptive capacity. Glob. Environ. Chang. 16(3): 293-303. doi: 10.1016/j.gloenvcha.2006.02.004.

Gauthier, S., P. Bernier, P.J. Burton, J. Edwards, K. Isaac, N. Isabel, K. Jayen, H. Le Goff and E.A. Nelson. 2014. Climate change vulnerability and adaptation in the managed Canadian boreal forest. Environ. Rev. 22: 1-30. doi:10.1139/er-2013-0064.
Gielen, B. and R. Ceulemans. 2001. The likely impact of rising atmospheric $\mathrm{CO}_{2}$ on natural and managed Populus: A literature review. Environ. Pollut. 115(3): 335-358. doi:10.1016/S02697491(01)00226-3.

Girardin, M.P., X.J. Guo, P.Y. Bernier, F. Raulier and S. Gauthier. 2012. Changes in growth of pristine boreal North American forests from 1950 to 2005 driven by landscape demographics and species traits. Biogeosciences Discuss. 9(1): 2523-2536. doi:10.5194/bg-92523-2012.

Girardin, M.P., X.J. Guo, R. De Jong, C. Kinnard, P. Bernier and F. Raulier. 2014. Unusual forest growth decline in boreal North America covaries with the retreat of Arctic sea ice. Glob. Chang. Biol. 20(3): 851-866. doi:10.1111/gcb.12400.

Houle, D., A. Bouffard, L. Duchesne, T. Logan and R. Harvey. 2012. Projections of future soil temperature and water content for three Southern Quebec forested sites. J. Clim. 25(21): 7690-7701. doi:10.1175/JCLI-D-11-00440.1.

IPCC. 2001. McCarthy, J.J. Canziani, O.F. Leary, N.A. Dokken, D.J. White, K.S. (eds.). Climate change 2001: impacts, adaptation, and vulnerability: Contribution of Working Group II to the third assessment report of the Intergovernmental Panel on Climate Change. Cambridge University Press, Cambridge, UK.

IPCC. 2014. Agard, J. et al. (eds.). Annex XX: Glossary, Climate Change 2014: Impacts, Adaptation, and Vulnerability. Part B: Regional Aspects. Contribution of Working Group II to the Fifth Assessment Report of the Intergovernmental Panel on Climate Change. Cambridge University Press, Cambridge, United Kingdom and New York, NY, USA.

Johnston, M., T. Williamson, A. Munson, A. Ogden, M. Moroni, R. Parsons, D. Price and J. Stadt. 2010. Climate Change and Forest Management in Canada: Impacts, Adaptive Capacity and Adaptation Options. A state of knowledge report. Edmonton, Alberta.

Kerr, R.A. 2011. Vital Details of Global Warming are Eluding Forecasters. Science 334(6053): 173-174. doi:10.1126/science.334.6053.173.

Khadka, C., T. Hujala, B. Wolfslehner and H. Vacik. 2013. Problem structuring in participatory forest planning. For. Policy Econ. 26(0): 1-11. doi:10.1016/j.forpol.2012.09.008.

Kirilenko, A.P. and R.A. Sedjo. 2007. Climate change impacts on forestry. Proc. Natl. Acad. Sci. U. S. A. 104(50): 19697-19702. doi:10.1073/pnas.0701424104.

Knoke, T., B. Stimm, C. Ammer and M. Moog. 2005. Mixed forests reconsidered: A forest economics contribution on an ecological concept. For. Ecol. Manage. 213(1-3): 102-116. doi:10.1016/j.foreco. 2005.03.043

Lapointe-Garant, M.-P., J.-G. Huang, G. Gea-Izquierdo, F. Raulier, P. Bernier and F. Berninger. 2010. Use of tree rings to study the effect of climate change on trembling aspen in Québec. Glob. Chang. Biol. 16(7): 2039-2051. doi:10.1111/j.1365-2486.2009. 02048.x.

Lemmen, D.S., F.J. Warren, J. Lacroix and E. Bush (eds.). 2008. From impacts to adaptation: Canada in a changing climate 2007. Government of Canada, Ottawa, Ontario.

Lindner, M., B. Sohngen, L.A. Joyce, D.T. Price, P.Y. Bernier and T. Karjalainen. 2002. Integrated forestry assessments for climate change impacts. For. Ecol. Manage. 162(1): 117-136. doi:10.1016/ S0378-1127(02)00054-3.

Loehle, C. and D. LeBlanc. 1996. Model-based assessments of climate change effects on forests: A critical review. Ecol. Modell. 90(1): 1-31. doi:10.1016/0304-3800(96)83709-4.

Logan, T., I. Charron, D. Chaumont and D. Houle. 2011. Atlas of Climate Scenarios for Québec Forests. Ouranos and MRNF.

Magnan, A. 2009. Proposition d'une trame de recherche pour appréhender la capacité d'adaptation au changement climatique. VertigO 9(3): 1-20. doi:10.4000/vertigo.9189. 
Magnan, A. 2010. Dossier " Adaptation aux changements climatiques »-Questions de recherche autour de ladaptation au changement climatique. Natures Sci. Sociétés 18(3): 329-333. doi:10.1051/nss/2010041.

McDowell, N.G., D.J. Beerling, D.D. Breshears, R.A. Fisher, K.F. Raffa and M. Stitt. 2011. The interdependence of mechanisms underlying climate-driven vegetation mortality. Trends Ecol. Evol. 26(10): 523-532. doi:10.1016/j.tree.2011.06.003.

McKenney, D.W., J.H. Pedlar, K. Lawrence, K. Campbell and M.F. Hutchinson. 2007. Potential Impacts of Climate Change on the Distribution of North American Trees. Bioscience 57(11): 939. doi:10.1641/B571106.

Meinke, H., S.M. Howden, P.C. Struik, R. Nelson, D. Rodriguez and S.C. Chapman. 2009. Adaptation science for agriculture and natural resource management - urgency and theoretical basis. Curr Opin. Environ. Sustain. 1(1): 69-76. doi:10.1016/j.cosust. 2009.07.007.

Metsaranta, J.M., C.C. Dymond, W.A. Kurz and D.L. Spittlehouse. 2011. Uncertainty of 21st century growing stocks and GHG balance of forests in British Columbia, Canada resulting from potential climate change impacts on ecosystem processes. For. Ecol. Manage. 262(5): 827-837. doi:10.1016/j.foreco.2011.05.016

Milad, M., H. Schaich, M. Bürgi and W.Konold. 2011. Climate change and nature conservation in Central European forests: A review of consequences, concepts and challenges. For. Ecol. Manage. 261(4): 829-843. doi:10.1016/j.foreco.2010.10.038.

Millar, C.I., N.L. Stephenson and S.L. Stephens. 2007. Climate change and forests of the future: Managing in the face of uncertainty. Ecol. Appl. 17(8): 2145-2151. doi:10.1890/06-1715.1.

Moser, S.C. and J.A. Ekstrom. 2010. A framework to diagnose barriers to climate change adaptation. Proc. Natl. Acad. Sci. U. S. A. 107(51): 22026-22031. doi:10.1073/pnas.1007887107.

Nemani, R.R., C.D. Keeling, H. Hashimoto, W.M. Jolly, S.C. Piper, C.J. Tucker, R.B. Myneni and S.W. Running. 2003. Climate-driven increases in global terrestrial net primary production from 1982 to 1999. Science 300(5625): 1560-1563. doi:10.1126/science.1082750. Ogden, A.E. and J.L. Innes. 2007. Perspectives of forest practitioners on climate change adaptation in the Yukon and Northwest Territories of Canada. Forest. Chron. 83(4): 557-569. doi:10.5558/ tfc83557-4.

Ogden, A.E. and J.L. Innes. 2009. Application of structured decision-making to an assessment of climate change vulnerabilities and adaptation options for sustainable forest management. Ecol. Soc 14(1): 11 .

Ohlson, D.W., G.A. McKinnon and K.G. Hirsch. 2005. A structured decision-making approach to climate change adaptation in the forest sector. Forest. Chron. 81(1): 97-103. doi:10.5558/tfc81097-1.

Périé, C., S. de Blois, M.-C. Lambert and N. Casajus. 2014. Effets anticipés des changements climatiques sur l'habitat des espèces arborescentes au Québec. Gouvernement du Québec, ministère des Ressources naturelles, Direction de la recherche forestière, Mémoire de recherche forestière $\mathrm{N}^{\circ} 173$.

Price, D.T., R.I. Alfaro, K.J. Brown, M.D. Flannigan, R.A. Fleming, E.H. Hogg, M.P. Girardin, T. Lakusta, M. Johnston, D.W. McKenney, J.H. Pedlar, T. Stratton, R.N. Sturrock, I.D. Thompson, J.A. Trofymow and L.A. Venier. 2013. Anticipating the consequences of climate change for Canada's boreal forest ecosystems. Environ. Rev. 21(4): 322-365. doi:10.1139/er-2013-0042.

Putnam, R.D. 1993. The Prosperous Community: Social Capital and Public Life. Am. Prospect 13: 35-42.

Raulier, F., H. Le Goff, S. Gauthier, R. Rapanoela and Y. Bergeron. 2013. Introducing two indicators for fire risk consideration in the management of boreal forests. Ecol. Indic. 24(0): 451-461. doi:10.1016/j.ecolind.2012.07.023.
Root, T.L., J.T. Price, K.R. Hall, S.H. Schneider, C. Rosenzweig and J.A. Pounds. 2003. Fingerprints of global warming on wild animals and plants. Nature 421(6918): 57-60. doi:10.1038/nature01333. Rustad, L., J. Campbell, J.S. Dukes, T. Huntington, K. Fallon Lambert, J. Mohan and N. Rodenhouse. 2012. Changing climate, changing forests: The impacts of climate change on forests of the northeastern United States and eastern Canada. Gen. Tech. Rep. NRS-99. Newtown Square, PA.

Ryan, M. 1991. Effects of climate change on plant respiration. Ecol. Appl. 1(2): 157-167. doi:10.2307/1941808.

Saxe, H., M.G.R. Cannell, Ø. Johnsen, M.G. Ryan and G. Vourlitis. 2001. Tree and forest functioning in response to global warming. New Phytol. 149(3): 369-400. doi:10.1046/j.1469-8137.2001. 00057.x.

Scheraga, J. and A. Grambsch. 1998. Risks, opportunities and adaptation to climate change. Clim. Res. 11(1): 85-95. doi: 10.3354/cr011085.

Smit, B., I. Burton, R.J.T. Klein and J. Wandel. 2000. An anatomy of adaptation to climate change and variability. Clim. Change 45(1): 223-251. doi:10.1023/A:1005661622966.

Smit, B. and O. Pilifosova. 2001. Adaptation to climate change in the context of sustainable development and equity, in: Climate Change 2001: Impacts, Adaptation, and Vulnerability- Contribution of Working Group II to the Third Assessment Report of the Intergovernmental Panel on Climate Change. Cambridge University Press, Cambridge, UK, pp. 877-912.

Smit, B. and J. Wandel. 2006. Adaptation, adaptive capacity and vulnerability. Glob. Environ. Chang. 16(3): 282-292. doi:10.1016/ j.gloenvcha.2006.03.008.

Smit, B., I. Burton, R.J.T. Klein and R. Street. 1999. The Science of Adaptation: A Framework for Assessment. Mitig. Adapt. Strateg. Glob. Chang. 4(3-4): 199-213. doi:10.1023/A:1009652531101.

Spittlehouse, D.L. and R.B. Stewart. 2004. Adaptation to climate change in forest management. J. Ecosyst. Manag. 4(1): 1-11.

Tompkins, E.L. and W.N. Adger. 2004. Does Adaptive Management of Natural Resources Enhance Resilience to Climate Change? Ecol. Soc. 9(2).

Van Mantgem, P.J., N.L. Stephenson, J.C. Byrne, L.D. Daniels, J.F. Franklin, P.Z. Fulé, M.E. Harmon, A.J. Larson, J.M. Smith, A.H. Taylor and T.T. Veblen. 2009. Widespread increase of tree mortality rates in the western United States. Science 323(5913): 521-524. doi:10.1126/science.1165000.

Vogel, C., S.C. Moser, R.E. Kasperson, and G.D. Dabelko. 2007. Linking vulnerability, adaptation, and resilience science to practice: Pathways, players, and partnerships. Glob. Environ. Chang. 17(3-4): 349-364. doi:10.1016/j.gloenvcha.2007.05.002.

Volney, W.J.A. and R.A. Fleming. 2000. Climate change and impacts of boreal forest insects. Agric. Ecosyst. Environ. 82(1-3): 283-294. doi:10.1016/S0167-8809(00)00232-2.

Weber, M.G. and M.D. Flannigan. 1997. Canadian boreal forest ecosystem structure and function in a changing climate: impact on fire regimes. Environ. Rev. 5(3-4): 145-166. doi:10.1139/a97-008. Williams, A.P., C.D. Allen, A.K. Macalady, D. Griffin, C.A. Woodhouse, D.M. Meko, T.W. Swetnam, S.A. Rauscher, R. Seager, H.D. Grissino-Mayer, J.S. Dean, E.R. Cook, C. Gangodagamage, M. Cai and N.G. McDowell. 2013. Temperature as a potent driver of regional forest drought stress and tree mortality. Nat. Clim. Chang. 3(3): 292-297. doi:10.1038/nclimate1693.

Williams, B.K. 2011. Passive and active adaptive management: Approaches and an example. J. Environ. Manage. 92(5): 1371-1378. doi:10.1016/j.jenvman.2010.10.039.

Williamson, T.B., J.R. Parkins and B.L. McFarlane. 2005. Perceptions of climate change risk to forest ecosystems and forest-based communities. Forest. Chron. 81(5): 710-716. doi:10.5558/tfc81710-5. 